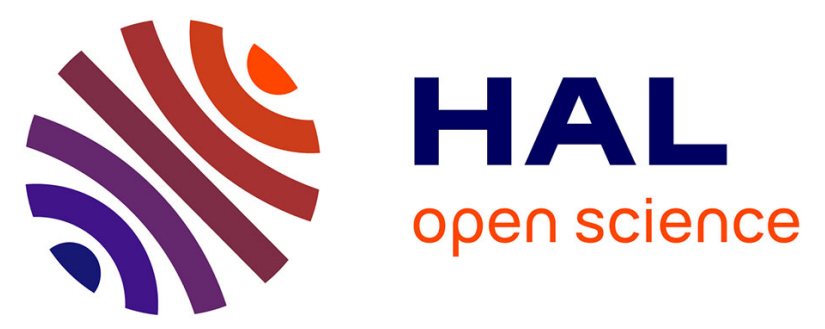

\title{
Freedom to Hold or Not to Hold Group Beliefs: The Case of Religious Beliefs in French and Polish Public School Textbooks
}

Sébastien Urbanski

\section{- To cite this version:}

Sébastien Urbanski. Freedom to Hold or Not to Hold Group Beliefs: The Case of Religious Beliefs in French and Polish Public School Textbooks. Religion \& Education, 2012, 39 (3), 10.1080/15507394.2012.716349 . halshs-01491448v2

\author{
HAL Id: halshs-01491448 \\ https://shs.hal.science/halshs-01491448v2
}

Submitted on 11 Feb 2019

HAL is a multi-disciplinary open access archive for the deposit and dissemination of scientific research documents, whether they are published or not. The documents may come from teaching and research institutions in France or abroad, or from public or private research centers.
L'archive ouverte pluridisciplinaire HAL, est destinée au dépôt et à la diffusion de documents scientifiques de niveau recherche, publiés ou non, émanant des établissements d'enseignement et de recherche français ou étrangers, des laboratoires publics ou privés. 


\title{
Freedom to Hold or Not to Hold Group Beliefs: The Case of Religious Beliefs in French and Polish Public School Textbooks
}

Religion \& Education, vol. 39-3, 2012, p. 308-319.

\author{
Sébastien Urbanski
}

\begin{abstract}
In French public schools, the project of improving the teaching about religions is being made possible thanks to various recent ministerial reports and pedagogical reforms. The latter put an emphasis on positive liberty, since they contain the view that pupils should commit to a way of self-realization. On the contrary, Polish laws on textbooks put an emphasis on negative liberty. This article is an attempt to evaluate the advantages and limits of enhancing each of these kinds of liberty, as far as pupils' own freedom to believe or not to believe is concerned.
\end{abstract}

Key words: Secularism, School, Group belief, Textbooks

\section{Introduction}

Teaching about religions in public schools seems necessary because of the increasing diversity of Western societies, since many contemporary conflicts are due to the ignorance of different 
cultures, including religions. However, giving too much importance to religions in educational media could generate various forms of discrimination either towards the many pupils who do not identify with any religion, or towards those who identify with a different religion from the one which is taught. This problem may be resolved if teaching about religions is clearly distinguished from the imposition of religious beliefs; however, as I shall try to show, this distinction is easier to theorize than to apply.

As is well known, French laïcité (the French version of secularism) tends to forbid the expression, by teachers or teaching contents, of any religious belief in public schools. Thus, it prevents pupils from the imposition of a dominant religion's view and avoids the discrimination against non-believers. But it has important defects. According to many French communitarians, laïcité favors mutual ignorance among citizens and prevents various religious communities from identifying positively to state institutions. That is the reason why many intellectuals philosophers, historians, sociologists - defend the "teaching of religious fact" (enseignement $d u$ fait religieux), better translated as "teaching about religion(s)", according to which school curricula should take into account the religious dimension of human life. Among these intellectuals, some have written official ministerial reports ${ }^{1}$ which today bind the Ministry of Education to make a larger place for teaching about religions. On the one hand, this shift seems positive because it takes some distance with the supposed dogmatic dimensions of laïcité; but on the other hand, some of its concrete applications could generate discrimination towards nonbelievers and other-believers - as we will see below.

In Poland, contrary to widespread belief, textbooks are not under control of the Catholic Church. Polish educational law includes references to "Christian values" and the Polish 
Constitution recognizes special rights for the Catholic Church, but it does not have much direct influence on textbooks. It only has indirect influence, as one cannot publicly contest - for instance before the Constitutional Court - a possible transgression of the religious neutrality. The main problem linked to the religious neutrality is elsewhere. Polish textbooks are not controlled by the Church, but they are not highly controlled by the state, either: the postcommunist school reforms have been concretized by the state's sharp withdrawal from textbook regulation. As a result, Polish textbook authors enjoy significant freedom ${ }^{2}$, at least compared to their French counterparts. On the one hand, this kind of freedom is desirable because it helps avoid state (or Church) ideological control of school curriculum. But on the other hand, it does not permit the religious neutrality of textbooks because their authors tend to introduce their personal religious convictions into course content in public schools. This does not seem to be compatible with either the contemporary religious diversity in Poland, or with the growing nonreligious views in this country.

This article is an attempt to put forward a theoretical framework which could heuristically grasp the issues raised by the presence of knowledge about religions in educational media, and to apply it to the case of French and Polish textbooks. Insights are drawn from three different fields:

- political science, because political decisions have an impact on textbooks and on their democratic or non-democratic character;

- sociology of group beliefs, because a potential danger of teaching about religions is to impose some dominant religious groups' views (though admittedly, not teaching about religions can lead to the same kind of danger, as in communist Poland); 
- sociology of science, because the intellectual context which students face contains parallels to that which scientists face, as Weinbrenner has suggested ${ }^{3}$.

In the first place (parts 2 and 3), I present the broad contemporary transformations of the teaching about religions in both countries and the potential problems they imply. In the second place (part 4), I put forward a theoretical framework which further highlights these problems. In the third place (parts 5 and 6), I propose a concrete study of pedagogical instructions, history textbooks and multidisciplinary textbooks. All translations from French and Polish are mine.

\section{The rise of "Enseignement du fait religieux" in France}

A general question raised by the problems mentioned above can be formulated as follows: what kind of educational media content is compatible with a democratic school able to ensure an education to diversity? The answer to this question depends on one's idea of democracy and liberty. Many authors defend positive liberty, i.e. the liberty to decide politically for oneself in order to attain self-realization ${ }^{4}$. Rousseau's political conception of contractualism is of this kind: citizens obey laws that they have decided on without delegates or any other intermediaries. Communitarian versions of French laïcité are of this kind too: they are based on the idea that each citizen is committed to abandon, in the public sphere, his or her private religious beliefs in order to identify with the Republic (the common good) which, in turn,

permits each citizen to experience liberty ${ }^{5}$. Critics of this conception have pointed out that it is quite unrealistic in today's diverse, ultra-modern societies. But the French way of teaching about religions, as put forward recently, seems to imply a very similar form of positive liberty. 
Indeed, the author of the most influential ministerial report on the "enseignement du fait religieux", philosopher Régis Debray, is himself an ex-defender of the communitarian ("Rousseauist") version of laïcité and Republic. It is therefore not surprising that his report tends to imply the idea of the universality of religious belief ${ }^{6}$ : in Debray's opinion, everybody needed to believe in classical laïcité in the past, and everybody should believe in "something" today, by virtue of what he calls the "incompleteness principle" according to which no society could survive without a reference to an "exterior" point of anchor". The point of anchor par excellence seems to be God. In a chapter entitled "The Eternity of the Eternal", Debray writes: “'Hell is living in the absence of God', Cardinal Ratzinger, the Roman prefect of Catholic doctrine, rightly says, if we immediately specify that 'God' is one among other keystones that might be envisaged",

Similarly, in an influential book promoting the teaching about religions at school, François Boespflug, Françoise Dunand and Jean-Paul Willaime claim:

To believe, in the religious sense of this expression, is before all to see, or rather to engender a sense in what seems to lack it. Then, belief becomes a power which permits the construction of one's own existence (...). Attributing this power to an exterior entity may be illusory, that is not for the history of religion to decide; but is not the important thing to discover it [power] inside oneself? ${ }^{9}$

In other words, according to Boespflug, Dunand and Willaime, it is important to discover this very power "created" by religious belief (actually, as the word "becomes" suggest, the power in question rather seems to be a transformed religious belief). Today, Willaime is 
president of the Institut Européen en Sciences des Religions (IESR) which executes not only the Ministry of Education's but also the Council of Europe's recommendations about how religion should be taught as a part of a general education ${ }^{10}$. And Jean Lambert, the author of a 1989 ministerial report on teaching about religions, now proposes to "integrate Republic into the religious fact" ${ }^{\prime 1}$.

A sharp theory of positive liberty is palpable in these statements, despite the apparent radical shift in the French "Rousseauist" conception of the religious neutrality of educational media. Thus, there is a danger of replacing the exclusiveness of classical lä̈cité by a no less exclusive requirement to hold a religious or quasi-religious belief. One could ask if the French official way of teaching about religions is more realistic than the classical laïcité, and if it does

not sometimes tend to exclude non-believers who obviously are also part of diversity ${ }^{12}$.

\section{The rise of today's Polish textbook conception system: from an atheistic communist ascendancy on textbooks to a market ascendancy}

The Polish textbook system tends to favor negative liberty, i.e. what Philip Pettit calls liberty as non-interference (which can be identified as belonging to the liberal tradition ${ }^{13}$ ). This can be explained by the fact that the post-communist democratization of the Polish education system had been achieved by a liberal government - composed of well-known ministers such as Tadeusz Mazowiecki and Leszek Balcerowicz, who engineered Poland's post-Soviet "economic shock therapy", a program closely aligned with the ideals of negative liberty. The result is that almost anybody can write a textbook and very few institutions interfere with its production. To 
be sure, a liberal conception of textbooks could be compatible with religious neutrality as is more or less the case in the United States (where judiciary power has been quite efficient in refuting the scientific claims of Intelligent Design promoters), but this kind of compatibility is now impossible in Poland where neither school law nor Constitution includes neutrality ${ }^{14}$.

Actually, Mazowiecki's government has proposed in 1990 a religiously neutral school law. But the strong conservative-catholic opposition - which to a great extent continues today with the Law and Justice party founded by Lech Kaczyński - managed to implement, through Parliament, some of its views. The Christian values have been finally adopted with a narrow advantage of three voices among 256. As a result, on the one hand, Polish school law is not neutral (owing to conservative parliamentary opposition); but on the other hand, textbooks are not under control of Catholic Church (owing to government's liberalization) ${ }^{15}$. Concretely, the system of ex-post textbook evaluation had been reduced to a rating by academics chosen and directly paid by the publisher. Although the choice of these academics has to be done on the basis of a (sometimes long) list of specialists disclosed by the Ministry, and although the textbook evaluation system has been partly changed in 2004 by the social-democrat excommunist government ${ }^{16}$, many pedagogues claim that textbooks are under-regulated and therefore filled with mistakes. Krzysztof Kawalec argues that

it is difficult to expect that mistakes are going to disappear by themselves, under the pressure of receivers. (...) Only the Ministry of Education can make a try to regulate this situation. Of course, a return to a strongly state-controlled education is out of question. But on the other side, the number of textbooks shouldn't grow and grow each year ${ }^{17}$ 
Indeed, one problem is that it is very difficult to withdraw a textbook from use, and quite easy for a publisher to go through the evaluation process, so that the market almost singlehandedly decides which textbook is employed ${ }^{18}$. Similarly, it is impossible to cross a specialist off of the Ministry's list in the case of a documented mistake ${ }^{19}$. The same kind of problem applies to educational programs. Significantly, Stanisław Sławiński, the 1991 Polish curricula reforms director, has said: "the principle of choice is more important than the question whether these curricula will be wholly satisfactory" ${ }^{20}$. The priority given to choice turns out to be an acceptance of many textbook authors' personal beliefs, including religious beliefs - as will be shown below.

\section{A Theoretical Framework Borrowed from Sociology of Group Beliefs and Sociology of}

\section{Science}

Philosopher Philip Pettit, whose purpose is to conciliate dominant liberal and communitarian views, argues that the ideal of positive liberty - although seductive - is often interpreted in such a way that it leaves the door open to all kinds of public imperium: if the self has to be transcended by an assimilation to some superior totality (for example "the national spirit" or "the community spirit"), then private sphere is reduced to almost nothing. This is the main liberal argument against positive liberty ${ }^{21}$. But negative liberty leaves the door open to private dominium: if they are not interfered with by the law, those who have power can themselves arbitrarily interfere in the lives of the weakest individuals. This is one of the main republican and communitarian arguments against negative liberty ${ }^{22}$. 
In scientific life, favoring exclusively positive liberty is problematic. Scientific progress is possible if researchers are constrained by paradigms ${ }^{23}$, but it is hampered when those constraints are too unilateral. For example, physicist Niels Bohr publicly defined, in 1927, the "Copenhagen interpretation" in quantum mechanics, although he was not formally delegated by the Copenhagen group to take on this role. Thus, younger physicists (notably Heisenberg) had to collectively agree with Bohr, even if they personally disagreed with him. They had been "jointly committed"24 to Bohr's views, and therefore experienced domination (in this situation, an illegitimate form of intellectual constraint $)^{25}$. If they were jointly committed in the writing of a joint paper, or in participating to a collective review, they would probably experience positive liberty, deciding all together about the goals of their (scientific) community. But it was not the case, since Bohr has by himself defined the "Copenhagen interpretation" at a conference. Junior physicists could not publicly contest their master's view ${ }^{26}$.

More generally, according to social philosopher Margaret Gilbert, joint commitments can produce genuine collective beliefs - and positive liberty ${ }^{27}$ - in situations where each, in the group in question, is ready to be committed. However, according to social philosopher Alban Bouvier, these kinds of situations are rare in scientific context; often, "commitments that seem at first sight to be joint commitments (...) reveal themselves to be more plausibly mere unilateral commitments of junior scientists" 28 .

This illustrates the judgement made by liberals that positive liberty is an arduous ideal ${ }^{29}$. But in science, negative liberty ideal is no less problematic, since cumulativity of knowledge requires collectively planned research. In what follows, I will try to evaluate some concrete consequences of how teaching about religions is designed in French and Polish public schools, 
and especially to point out the inherent paradoxes that stem from situations in which either positive or negative liberty is favored in an exclusive manner ${ }^{30}$.

\section{Commitments resulting from the emphasis on self-realization in French history textbooks, multidisciplinary textbooks, and pedagogical instructions}

Does the "enseignement du fait religieux" require a joint commitment to some superior totality? According to Dominique Borne, who is president of the Institut Européen en Sciences des Religions direction council, it does not: "Evoking religion not from the inside of a belief but on a critical and historical manner is an essential prerequisite which guarantees that the teaching concerns knowledge, and not indoctrination"31. However, some of his other statements seem to imply a very demanding commitment: "Telling pupils that we all are sons of Abraham or Ibrahim is important and strong" ${ }^{32}$. The exact nature of the commitment implied by this sentence is hard to define: does this sentence mean that everybody should in some way believe in Abraham? Or does it just mean that our civilization or culture is "Abrahamic"? Instead of answering these difficult questions, I would like to point out the following: a pupil (or a parent) may interpret this sentence as requiring too demanding of a unilateral commitment to some more or less religious notion. What Borne probably meant is that Abraham can be considered the founder of both Christianity and Islam and that French pupils from different "cultures" could therefore understand each other - provided they recognize their "father". But one could ask whether all pupils are ready to recognize themselves as "sons of Abraham". More generally, it seems that according to Borne, social links require a joint commitment: "Being French is to 
adopt the Gauls as ancestors, French national myths, a common memory including Vercingétorix (a Gaulic chief), Jeanne d'Arc, Reims, Versailles, 1789, Jaurès, Clémenceau"33. If this statement is true, one could understand that finding some common ancestor for pupils from different "cultures" (the French one and the Muslim one?) is a matter of urgency. But it is doubtful that pupils are ready to be committed to a Gaulic or Abrahamic identity.

The same kind of problem can be identified in several curious formulations by religious representatives who, according to the Debray report, may be consulted in the textbook redaction process $^{34}$. For example, the Rabbi René-Samuel Sirat claims that "Youths from the suburbs have the right to know the fundamental values of their religion: 'no constraint in the religious domain' (Surat 2, verse 257 of the Koran) and 'One who saved an innocent life is like he has saved the whole mankind.' (Surat 5, verse 35 of the Koran)" (my italics) ${ }^{35}$. One could ask if all "youths from the suburbs" are actually committed to Islam.

Now I would like to present some samples of very concrete pedagogical propositions which are considered as in line with the Ministerial reports mentioned above. One textbook mentioned in the REDCo France bibliography ${ }^{36}$ states: "Every year, Jews thank God who rescued them during the exile in Egypt"; "In order to tell this, John writes thanks to the Holy Spirit" ${ }^{37}$. It proposes to ask pupils: "When you hear the word 'light', what does this evoke for you? In you?" (my italics). According to the manual, the teacher who should formulate this question is not the literature teacher, but the physics one. The latter also should, together with the literature teacher, read literary and religious texts in class.

One of the main defenders of the "enseignement du fait religieux", Mireille Estivalèzes, has designed a textbook for 11-year pupils in which she explains what a shaman is: "the shaman 
is a man who can travel in the world of spirits. He possesses certain powers such as the ability to cure diseases or predict the future". In order to make pupils understand, several blank lines are left for them to answer the question: "What is a shaman?"38. Similarly, in another textbook by the same author, it is said that Jesus is present in the Eucharistic hosts: "When he passes before the tabernacle, the practicing catholic kneels out of respect for Christ's body, present in the consecrated hosts" ${ }^{\prime 39}$.

Another official textbook proposes to organize physical exercises during the sport class, which comprise a "bodily expression of the Genesis theme of separation between light and darkness $" 40$. One could also mention the case of the following proposition which is presented by Ministry of Education's pedagogical editor as a method to teach about religions:

It is important to offer some meaning: the problem of our origins, the problem of death. What happens after death? (...) The ancient Greek religion does not give a fully satisfactory response (...). With the Romans, it is worse (...), their religious sensibility is not very rich (...). Then comes a man called Paul who tells us about a man by the name of Jesus (...) who offers us the kingdom of gods if we follow his teachings: how to resist? We are saved, the salvation is here! I think it is this way that we can teach laïcitét

I would like to specify that this method is designed for history lectures (although it is difficult to differentiate from a catechism).

\section{Commitments Resulting From the "Non-Interference" Production of Polish History}

\section{Textbooks}


Despite the fact that religious neutrality is not explicitly stated in the Constitution of Poland and despite the great institutional power of the Catholic Church, Polish textbooks are far from being filled with Catholic propaganda. This is probably due to the freedom which their authors enjoy. But this freedom has a drawback. Drawing on the above distinctions between various kinds of liberty, it can be said that Polish textbook authors enjoy freedom as noninterference: as suggested above, the system of post-production evaluation of textbooks is inefficient. It implies that textbook authors can arbitrarily interfere in pupils' private religious or non-religious beliefs, and this constitutes a form of domination - which could also be considered, following above-mentioned science studies, as a form of illegitimate intellectual constraint.

My empirical research, based on an analysis of 60 recent Polish history textbooks ${ }^{42}$, leads me to the following assertions:

Around $75 \%$ of history textbooks capitalize pronouns for Jesus as well as for his actions. One can thus find expressions like "the Master", "Pilate condemned Him to death", "the message about the Resurrection of Christ and about His return", "the Teaching of Jesus" "43. Therefore, $75 \%$ of Polish history textbooks contain the idea that Jesus is not simply a historical character, since capital letters refer to the divine, non-historical dimension.

Many textbooks speak of supernatural events: "[Jesus] confirmed his teaching with miracles, like curing terminal diseases and even raising people from death" 44 ; "After the death and resurrection of Jesus Christ, apostles left towards various directions in the world in order to claim the New Gospel" "45; "After resurrection and ascension of the Master, His adherents (...) 
began to form Christian communities"46; "The Jews had lived according to the instructions of a holy book inspired by God, called Bible"47; "The third day after the entombing of His body, Maria Magdalena, Maria Jacobi and Salome (Mark's Gospel) discovered that the tomb is empty. Then Jesus was seen in many places"48; "The image presents Jesus doing the first miracle. During a wedding in Cana Jesus changed water into wine" ${ }^{\text {,4 }}$. Some chapters about the beginnings of Christianity are entitled in a religious or a metaphysical manner: "You are Peter, the stone on which Church has been built"50; "'Until the end of the world",51. One textbook insists on Jesus' alleged Davidic genealogy (which is more of theological rather than historical importance): "Jesus was born in a family coming from the very king David"

Around $20 \%$ of history textbooks are not subject to this kind of problematic content. It might be worth mentioning the ones which draw distinctions between history and tradition: "According to [Christian] tradition - which is not tantamount to historical truth",53; "We know the image of Jesus' life and teaching from Christian tradition. It is not possible verify it, since authors of the only sources at our disposition were Christian" ${ }^{\text {, }}$. Several textbooks do not even speak of Jesus, giving the emphasis on Christian beliefs in II and III century ${ }^{55}$, or on the economical aspects of Roman Empire ${ }^{56}$. This is not to say that it would be good to tell pupils that Christian tradition is "false". But undoubtedly, some basic distinctions between tradition and history are useful.

The heterogeneity of the religious, areligious or anti-religious ${ }^{57}$ contents of Polish history textbooks is due to the negative liberty which their authors enjoy: the latter can decide if they are going to write about, say, Jesus' supernatural powers. Several authors take the liberty of omitting the very beginnings of Christianity. Others speak of Jesus as historical character. But 
most authors take the liberty to interfere in pupils' beliefs by introducing their personal religious convictions in textbooks.

In this regard, it is interesting to follow the evolution of authors who wrote textbooks before and after communism's collapse. In recent publications, two of them capitalize pronouns for Jesus ${ }^{58}$, but used to employ lowercase letters before $1989^{59}$. This confirms that textbook authors' processes of writing heavily depend on the social (in this case institutional) context. I shall conclude this section borrowing Kawalec's terms: of course, a return to a strongly statecontrolled textbook system is out of question; but today's system leads to the proliferation of many authors' personal beliefs.

\section{Conclusion}

My general aim has not been to criticize "badly written" textbooks, as it is obviously very difficult to conceive of an education system which would fully ensure non-domination. If the religious contents of Polish textbooks were somehow controlled by the state, they would probably also be controlled by the Church (via the state), so that the "non-interference" conception of textbooks which is today in force has very tangible advantages. Nor is my aim to criticize French official way of teaching about religions: many sociologists have convincingly argued that it is necessary ${ }^{60}$. I simply hoped to point out that some concrete proposals inspired by this idea are no more compatible with diversity than some versions of classical laïcité, which many authors consider, rightly or wrongly, as outdated ${ }^{61}$. 
1 Philippe Joutard, Rapport de la mission de réflexion sur l'enseignement de l'histoire, la géographie et les sciences sociales (Paris: Ministère de l'Éducation Nationale, 1989); Régis Debray, L'enseignement du fait religieux dans l'école laïque (Paris: Odile Jacob, 2002). These reports are in accordance with the policy recommendations of the REDCo Project, which has been presented in Religion and Education vol. 37, 3, 2010.

2 Krzysztof Kawalec, "Problemy obfitości" (Problems of Quantity), in Prace komisji do oceny podręczników szkolnych, Tom VI (Kraków: Wyd. PAU, 2008): 9-15.

3 "If the schoolbook is a medium by which the experiences of pupils in the world are organized, explained and made comprehensible by means of scientific methods, the scientific principles applied to the design and analysis of schoolbooks must be the same as those used in the scientific search for knowledge itself". Peter Weinbrenner, "Methodologies of Textbook Analysis used to date", in Hilary Bourdillon, History and Social Studies Methodologies of Textbook Analysis (Amsterdam: Swets and Zeitlinger, 1992), 24. For a recent application of this Weinbrenner's intuition, see Katalin Morgan, "Reflexive Grappling with Theory and Methods of Text Analysis: Race and Racism Represented in History Textbooks", South African Historical Journal Vol. 62, 4 (2010).

4 Or, as Quentin Skinner puts it, "negative liberty is freedom from constraint; positive liberty is freedom to follow a certain form of life". See Skinner, "A Third Concept of Liberty" in Robert Goodin and Philip Pettit, Contemporary Political Philosophy: an Anthology (Oxford: Blackwell, 2006), 399.

5 About the links between Rousseau and French laïcité, see Philip Pettit, "Republicanismo Cívico", conferencia de Philip Pettit organizada por el Centro de Estudios Andaluces, 13 march 2008, http://www.centrodeestudiosandaluces.es/

6 As Bouveresse and Kintzler argue. Jacques Bouveresse, Peut-on ne pas croire? Sur la vérité, la croyance et la foi (Marseille: Agone, 2007); Catherine Kintzler, Qu'est-ce que la laïcité ? (Paris: Vrin, 2007).

7 Debray was one of the main targets of Sokal and Bricmont during the "Sokal affair". Defenders of the rationalist conception of science blamed him for having claimed that Gödel's incompleteness theorem (in mathematical logic) demonstrates that human societies need to refer to a point of anchor situated "outside" them. Alan Sokal 
and Jean Bricmont, Intellectual Impostures: Postmodern Philosopher's Abuse of Science (London: Profile Books, 1998).

8 Régis Debray, God: an Itinerary (London: Verso, 2004), 280.

9 François Boespflug, Françoise Dunand, Jean-Paul Willaime, Pour une mémoire des religions (Paris: La Découverte, 1996), 31. The original text is as follows: "Croire, au sens religieux du terme, c'est avant tout voir, ou plutôt faire naître un sens dans ce qui paraît en être dépourvu. La croyance devient alors une force qui permet de construire son existence et en même temps d'agir efficacement pour les autres. Qu'on attribue cette force à une entité extérieure à soi est peut-être illusoire ; l'histoire des religions n'a pas à en décider ; mais l'important n'est-il pas de la découvrir en soi ?"

10 See Council of Europe's recommendation 1720 (2005) on "Education and religion": http://assembly.coe.int/main.asp?Link=/documents/adoptedtext/ta05/erec1720.htm. The English text refers to "religious studies", the French one adopts the expression "enseignement du fait religieux".

11 A better translation could be: integrating Republic into religion. Jean Lambert, "Avènement du fait religieux et pratiques de laïcité dans l'enseignement", in Dominique Borne, ed. Laïcité, vérité, enseignement (Dijon: CRDP de Bourgogne, 2006), 9.

12 Kintzler, Qu'est-ce que la laïcité, 67. Kintzler defends a non-rousseauist and non-contractualist conception of laïcité. She is rather inspired by Nicolas de Condorcet.

13 Philip Pettit, Republicanism: A Theory of Freedom and Government (Oxford: Oxford University Press, 1999).

14 Jarosław Szymanek, "Stosunki wyznaniowe we współczesnej Polsce: elementy prawa i praktyki” (Confessional Relations in Today's Poland: Elements of Law and Practice), in Czesław Janik, ed. Polska w Unii Europejskiej a stosunki wyznaniowe (Toruń: Adam Marszałek, 2005).

15 Sébastien Urbanski, "La démocratisation des contenus d'enseignement à l'école publique en Pologne: essai d'analyse des justifications politiques des réformes scolaires à la sortie du communisme”, Education et Sociétés. Revue internationale de sociologie de l'éducation, 27 (2011).

16 Rozporządzenie Ministra Edukacji Narodowej i Sportu z dnia 5 lutego 2004 r. w sprawie dopuszczania do 
użytku szkolnego programów wychowania przedszkolnego, programów nauczania i podreczników oraz cofania dopuszczenia (Ministry of Education decree about authorization and withdrawing authorization to use teaching programs and textbooks, $5^{\text {th }}$ February 2004).

17 Kawalec, "Problemy obfitości”, 14.

18 Ibid., 12.

19 Krzysztof Fiałkowski, "Uwagi o projekcie rozporządzenia MEN w sprawie dopuszczania do użytku szkolnego programów wychowania przedszkolnego, programów nauczania i podręczników oraz cofania dopuszczenia, 29 grudzień 2008” (Remarks on Ministry of Education decree about authorization and withdrawing authorization to use teaching programs and textbooks, $29^{\text {th }}$ December 2008), www.ptf.agh.edu.pl/SN/fialkowski 5.pdf . Fiałkowski is member of the Polish Academy of Skills Commission on Schoolbooks Evaluation.

20 Stanisław Sławiński, "Wywiad na temat reform programowych" (Interview about curricula reforms) Nowa Szkoła, September 1991.

21 See also Isaiah Berlin, Liberty (Oxford: Oxford University Press, 2002).

${ }^{22}$ For another attempt to grasp the issues raised by the distinction between positive and negative liberty, see Charles Taylor, “What's Wrong with Negative Liberty?”, in Charles Taylor's Philosophical Papers (Cambridge: Cambridge University Press, 1985).

23 Thomas S. Kuhn, The Structure of Scientific Revolutions, (Chicago: The University of Chicago Press, 1962).

24 This notion is drawn from Margaret Gilbert, On Social Facts, (London, New York: Routledge, 1989).

25 According to Mara Beller, Bohr has constructed a "dogma" since 1927 (the "Copenhagen dogma"). Mara Beller, Quantum Dialogue: the Making of a Revolution, (Chicago: The University of Chicago Press, 1999). A similar analysis is made by Gilbert on the example of the recent discovery of ulcer bacteria, see Margaret Gilbert, "Collective Belief and Scientific Change", Sociality and Responsibility: New Essays on Plural Subject Theory (New York: Rowman and Littlefield, 2000), 37-49.

${ }^{26}$ Alban Bouvier, "Individual Beliefs and Collective Beliefs in Sciences and Philosophy: The Plural Subject and the Polyphonic Subject Accounts: Case Studies”, Philosophy of the Social Sciences, vol. 34, 3 (2004): 382-407. 
27 Margaret Gilbert, A Theory of Political Obligation: Membership, Commitment, and the Bonds of Society (Oxford: Oxford University Press, 2006), 66.

28 Bouvier, "Joint Commitment, Coercion and Freedom in Science. Conceptual Analysis and Case Studies", in Jeroen Van Bouwel (ed), The social sciences and democracy (Palgrave Macmillan, 2009), 153.

29 About positive liberty, Berlin writes: "Whatever is the true goal of man (...) must be identical with his freedom" (quoted by Skinner, ibid, 399). His argument is that institutions of power (State, Church...) often decide what should be the "true goal of man", which finally leaves few liberty to the individual.

30 Cécile Laborde tries to evaluate the feasibility of Pettit's theory of liberty regarding secularism in French public schools. Cécile Laborde, Critical Republicanism: The Hijab Controversy and Political Philosophy (Oxford : Oxford University Press, 2008)

31 Dominique Borne, "Enseigner les dimensions religieuses des cultures à l'école lä̈que?", in Cahiers français, 340 (2007): 18.

32 Dominique Borne, "Pourquoi parler du fait religieux ?" in Jean-Marie Husser, Religions et modernité (Versailles: Centre Régional de la Documentation Pédagogique, 2004), 20.

33 Ibid, 21.

34 Above-mentioned Council of Europe recommendation also advises the consultation of religious representatives.

35 René-Samuel Sirat (with Philippe Capelle and Dalil Boubakeur), L'enseignement des religions à l'école laïque (Paris: Salvator, 2003), 15.

${ }^{36}$ www.iesr.ephe.sorbonne.fr/index $4026 . \mathrm{html}$. See also above, note 1.

37 René Nouailhat (with Jean Joncheray), Enseigner les religions au collège et au lycée: 24 séquences pédagogiques (Besançon: Centre Régional de la Documentation Pédagogique, 1999), "fiche élève".

38 Mireille Estivalèzes (with Christian Defebvre), Sagesses et religions du monde, classe de 6ème. Cahier de travaux pratiques (Paris: Bayard, 2001), 3.

39 Mireille Estivalèzes (with Christian Defebvre), Les lieux du sacré, classe de 4ème. Cahier de travaux pratiques (Paris: Bayard, 2010), 13. 
40 Khashayar Azmoudeh, Cécile Becker, Maud Lasseur, Nathalie Toye, Anna Van den Kerchove, Anne Zali, Récits de création (Paris: La Documentation française, 2009), 92.

41 Béatrice Legris, séance pédagogique in Faits religieux et laïcité aujourd'hui (Versailles: Centre Régional de la Documentation Pédagogique et Institut Européen en Sciences des Religions, 2006), 1 DVD.

42 From three libraries: the Biblioteka Jagiellońska (Kraków, Poland), the Małopolska Biblioteka Publiczna (Kraków, Poland), and the Georg Eckert Institute for International Textbook Research library (Braunschweig, Germany).

43 Leszek Mrozewicz and Robert Świegocki, Historia (Poznań: Nowa Era, 2002): 170.

44 Tomasz Małkowski and Jacek Rześniowiecki, Historia i społeczeństwo (Gdańsk: Gdańskie Wyd. Oświatowe, 2001): 164 .

45 Maria Pietracha, Historia I, (Warszawa: Wyd. Szkolne i Pedagogiczne, 2001): 19.

46 Krzysztof Polek, Marek Wilczyński, Historia. Z pegazem (Kraków: Znak, 2002): 158.

47 Anna Wołosik, Historia. Opowiem Ci ciekawą historię (Warszawa: Żak, 1999): 127.

48 Dorota Granoszewska-Babiańska, Tytus Izdebski, Dariusz Ostapowicz, Sławomir Suchodolski, Historia. Dzieje kultury (Warszawa: Nowa Era, 2004): 168-169.

49 Radosław Lolo, Anna Pieńkowska, Rafał Towalski, Historia wokół nas (Warszawa: Wyd. Szkolne i Pedagogiczne, 2009): 99.

50 Kazimierz Przybysz, Wojciech Jakubowski, Mariusz Włodarczyk, Historia dla gimnazjalistów (Warszawa: Oficyna Edukacyjna, 2000): 101.

51 Tomasz Małkowski and Jacek Rześniowiecki, Historia I (Gdańsk: Gdańskie Wyd. Oświatowe, 2000): 148.

52 Krystyna Starczewska, Świat Starożytny (Warszawa: Wyd. Szkolne PWN, 1999): 121.

53 Wypustek Andrzej and Marek Wójcik, Historia I: Starożytność, Średniowiecze (Warszawa-Wrocław: Wyd. Atlas, 2002): 127.

54 Pawel Żmudzki, Historia: Starożytność, Średniowiecze (Warszawa: Stentor, 2005): 104. 
55 Anna Krzyszowska and Andrzej Wypustek, Historia: Starożytność (Wrocław: Wiking, 2002).

56 Michał Kosznicki, Sławomir Kotarski and Jacek Pudliszewski, Historia I (Wrocław: Wiking, 2002).

57 Not mentioning Jesus could be interpreted as an anti-religious stance.

58 Ewa Wipszycka, Historia dla Maturzysty. Starożytność (Warszawa: Wyd. Szkolne PWN, 2004); Lech Chmiel, Historia (Warszawa: Muza Szkolna, 2000).

59 Ewa Wipszycka, Historia: Starożytność (Warszawa: Wyd. Szkolne i Pedagogiczne, 1985); Janusz Adamski, Lech Chmiel and Andrzej Syta, Czasy, ludzie, wydarzenia. Cz. 1 (Warszawa : Wyd. Szkolne i Pedagogiczne, 1981).

60 Notably Mireille Estivalèzes, Les religions dans l'enseignement lä̈que (Paris: Presses Universitaires de France, 2005).

61 Jean-Paul Willaime, Le retour du religieux dans la sphère publique: vers une lä̈cité de reconnaissance et de dialogue (Lyon: Olivétan, 2008). 